\title{
Unlocking the Relationship Between Talent Management Practices and Performance Sustainability in the Sports Industry
}

Abdul Gaffar Khan, Mawlana Bhashani Science and Technology University, Tangail, Bangladesh

iD https://orcid.org/0000-0003-1031-2043

Somiron Banik, Mawlana Bhashani Science and Technology University, Tangail, Bangladesh

Md. Aftab Uddin, University of Chittagong, Chattogram, Bangladesh

https://orcid.org/0000-0002-9101-7451

Syed Moudud-Ul-Huq, Mawlana Bhashani Science and Technology University, Tangail, Bangladesh

iD https://orcid.org/0000-0002-9226-5131

\begin{abstract}
The present study investigated the effect of talent management practices on performance sustainability in the sports industry. The study used the deductive reasoning approach to predict new cricketer performance sustainability. The hypotheses were tested using partial least square structural equation modeling (PLS-SEM) techniques. The self-administered structured questionnaires were used to collect data. The total sample size was 270 , which were collected from respondents playing in Bangladesh Premier League domestic and international matches. The results revealed that onboarding and engagement, player development, performance management, and strategic teamwork planning positively influence performance sustainability. However, the findings suggested that policymakers and other concerned authorities should implement this result to sustain players' performance continuously. This is the first paper that applies talent management practices to magnify performance sustainability.
\end{abstract}

\section{KEYWORDS}

Onboarding and Engagement, Performance Management, Performance Sustainability, Player Development, Strategic Teamwork Planning, Talent Acquisition, Talent Management

\section{INTRODUCTION}

Over the past two decades, talent management has become a significant part of the managerial discussion and organizational practices in global competition (McDonnell, 2011). One of the most potent intangible assets of an organization is the employees' talent, i.e., human capital (Ramey et al., 2019; Wuen et al., 2020). Moreover, the resource-based firms demonstrated that the specific assets within an organization could give dynamic capabilities, which can be turned into sustainable 
competitive advantages, productivity, and prominent performance (Al Aina, \& Atan, 2020). In this case, talented employees are valuable resources for their distinctive competence that might encourage others to reproduce (Gelens et al., 2014; Maqueira et al., 2019).

The sports industry has relished productive growth in the recent decade (Teo, 2018). The sports industry represents a unique industry that involves people, actions and business activities inbound and outbound logistics (Bizen et al., 2018; Yeh et al., 2018). Customers' taste and fashion undergo change and shaped with the experiential marketing of sport celebrates. Subsequently, Ghai and Zipp (2020) and Tan and Pyun (2018) argued that sports industry makes revenue from by promoting other businesses through advertisements and sponsorship. Thus, sports industry has turned into a big market for businesses that offers a good platform for promoting their products and services (Da Silva, \& Las Casas, 2017; Kwak, \& Pradhan, (2020).

Furthermore, talent management can ensure optimal performance and achieve competitive advantages in the sports sector, like cricket. Notably, a reality check is essential regarding professional cricketers' talent management practices (Kerr \& Gladden, 2008; Kantor, Holdsworth, \& Barr, 2008; Khurshid \& Darzi, 2016). At present, why the most talented and experienced cricketers cannot keep their consistent performance is a significant concern. This study's significance will guide the policymakers to manage talent management concerning performance management efficiently.

Recently, researchers, entrepreneurs, businesspersons, and policymakers are exhibiting their interests to bring learning and insights into their critical areas for bringing novelty (Burnes \& O'Donnell, 2011; Megheirkouni, 2017). The study will also help broad cricket managers acknowledge talent management practices, leading to an increased level of perception about talent retention (Pandey, 2018). However, the sports coordinators, team managers, trainers, coaches, senior cricketers, junior cricketers, and trainees will get numerous benefits from this study. As per our knowledge goes, no study investigates the relationship between talent management and performance consistency in the sports industry.

This study contributes to the existing body of literature and practices in many ways. First, we extend the sustainable performance literature through identifying its antecedent and further nuance contributions into talent management literature and its effect on performance. Second, by finding out the stimulus factors in a new way that significantly influence performance sustainability in the sports industry, such as onboarding and engagement, player development, performance management, succession planning, strategic teamwork planning, and talent acquisition are the main influencing factors (Bartlett \& Hughes, 2015; Collings, Mellahi, \& Cascio, 2018). Third, even though the literature of talent management on performance is quite rich; however, recent studies in the sports sector lack the use of talent management on performance sustainability. Fourth, recently a very vibrant issue on sports and leisure was published in the International Journal of Asian Business and Information Management (Leng et al., 2018) in Asian perspective on Baseball (Shih et al., 2018), Football (Teo, 2018), children's sports (Bizen, 2018), sports brand apps (Byun, 2018). Despite the market for Cricket occupies a large space, this sports has been given a very little attention from academia. Surprisingly, no study on Cricket and its talent management is emphasized till now. Lastly, the research will find out the impact of talent management practices on performance sustainability among professional cricketers in the sports industry that can help facilitate the performers' consistent performance in any cricket tournaments in specific and other sectors in general.

\section{THEORETICAL FRAMEWORK AND HYPOTHESES DEVELOPMENT}

\subsection{Talent Management Practices and Performance Sustainability}

At present, talent management is a predetermined function of the cricketer's possessions because it provides a pathway toward the cricket board. Also, talent management is an ultra-critical function where the cricket board always strives to have a forward-looking approach to harness the best talent, 
closing all the talent gaps, and managing the talent to gain the best possible outcomes effectively and efficiently (Khurshid \& Darzi 2016). Performance sustainability means consistency performance, a successive strike-rate, a balanced run-rate, a proportional economy rate of the individual cricketers to maximize and sustain their team's performance. Bartlett and Hughes (2015) defined that a sustainable performance indicator is a combination of action variables that aim to define all performance aspects. Finally, taking these findings as a note, the study's goal is to examine the impact of talent management practices on performance. The research will also focus on the reasons for conducting talent management practices, its structures, and its perceived effect on team performance.

\subsection{Onboarding and Engagement as Well as Performance Sustainability}

Mainly, onboarding and engagement is a crucial driver of performance sustainability. It also represents an exclusive opportunity to set the stage for the rest of a cricketer's life cycle and consistent team performance. On the other hand, the meaningful connections with the most experienced and new cricketers can serve only two purposes: (1) it reinforces them access to subject matter experts who can accurately guide them, (2) the cricketers who are connected to the road (its purpose and culture) are far more engaged than those who are not (Collings, Scullion, \& Dowling, 2009). Chillakuri (2020) posited that effective onboarding and engagement strength performer psychological resources which in turn trigger them to perform more and more continually. Thus, it can be hypothesized as:

H1: Onboarding and engagement have a positive effect on performance sustainability.

\subsection{Player Development and Performance Sustainability}

Player development is the journey of a player that takes with their coach toward improving performance. Generally, a player's development is needed for building their learning, commitment, and hardworking capability, which are required for high-level performance. However, the essential skills, such as self-motivation, self-awareness, self-responsibility, and learning autonomy, are recognized as great importance for maintaining the cricketers' consistency performance (Martindale, Collins, \& Abraham, 2007). Jehanzeb (2020) and Mensah (2019) postulated that taking initiatives for talent development promote their emotional commitment i.e., citizenship behavior and subsequently influences them to perform consistency. Therefore, the hypothesis can be formulated as follows:

H2: Player development has a positive effect on performance sustainability.

\subsection{Performance Management and Performance Sustainability}

Nowadays, performance management is implemented in a wide variety of policy areas. The ideal ideas and practices can be gleaned from so many experiences (Gerrish, 2016). Performance management is the first and foremost duty of human resource managers to continuously support the talented cricketer's development and focus on the sports organizations' human resource management. In a word, performance management emphasizes benchmarking over time to provide a valid comparison and replicate the professional cricketers (Gerrish, 2016). Moreover, DeNisi and Murphy (2017) indicated that individuals perform with their consistence efforts, which result from accurate performance management. Hence, the hypothesis can be developed as follows:

H3: Performance management has a positive influence on performance sustainability.

\subsection{Succession Planning and Performance Sustainability}

Succession planning is a process that helps ensure the performance sustainability of the professional cricketers and is also used as a systematic effort designed to make sure sustainable performance. 
Ali and Mehreen (2019) argued that succession planning builds an individual's confidence because it generates psychological capability and resources to engage in their work efficiently. In addition, individual efficiency and effectiveness to achieve organizational goals is influenced by succession planning (Pennell, 2010). Moreover, succession planning generates a competitive advantage mentality against competitors, which improves professional development, and triggers consistent performance (Ali, Mahmood, \& Mehreen, 2019). Chakraborty and Biswas, (2020) elucidated that succession planning renders a positive link to performance sustainability through developing potential performers to achieve competitive advantages over rivalry. Consequently, the hypothesis can be formulated as follows:

H4: Succession planning has a positive effect on performance sustainability.

\subsection{Strategic Teamwork Planning and Performance Sustainability}

In general, a team's sustainable performance is higher than the individual performance when strategic teamwork planning requires a broader scope of judgment, knowledge, and professional cricketers' opinion. Besides, strategic teamwork planning creates an environment that facilitates more knowledge, information exchange, and knowledge sharing with the experienced cricketers (De Knop, Van Hoecke, $\&$ De Bosscher, 2004). On the other hand, the ability of new forms of the strategic teamwork planning enables the performance sustainability of the cricketers through the multi-skilling competencies in communication, problem-solving, and also supports the new ways of professional attitudes of the cricketers (Totterdill, Dhondt, \& Milsome, 2002; Davis, 1985). Indeed, Esfahani, Mosadeghrad, and Akbarisari (2018) contended that individuals expose to low performer due to the lack of sound strategy and actions, and vice versa. So, the hypothesis can be shown as below:

H5: Strategic teamwork planning has a positive effect on performance sustainability.

\subsection{Talent Acquisition and Performance Sustainability}

Currently, the "'war for talent'" has focused on acquiring and assimilating 'the best'. The cricketer's resources can play a significant role in achieving sustainable performance. Furthermore, talent has become the best key differentiator human capital management and leveraging competitive advantage. Maximizing motivation, retention, and team engagement through due diligence in talent acquisition is vital in today's highly competitive cricket world. A well-executed talent acquisition results are consistent and resilient performance (Ronn, 2007). Moghtadaie and Taji, (2016) and Al Aina and Atan (2020) elucidated that sustainable talent acquisition strategy leads to the continuance of sustainable performance. Thus, the hypothesis can be formulated as:

H6: Talent acquisition has a positive effect on Performance Sustainability.

Figure 1 reveals the conceptual framework entailing influences of onboarding and engagement, player development, performance management, succession planning, strategic teamwork planning, and talent acquisition on performance sustainability.

\section{METHODOLOGY}

\subsection{Sample and Procedures}

A convenience sampling method was applied to collecting data. The simple attitude scales and Likert Scale were used in categorizing the questions and answers. This study's sampling unit was Bangladeshi cricketers who are listed in Bangladesh Cricket Board (BCB) and Bangladesh Kriya Shikka Prosikkhon 


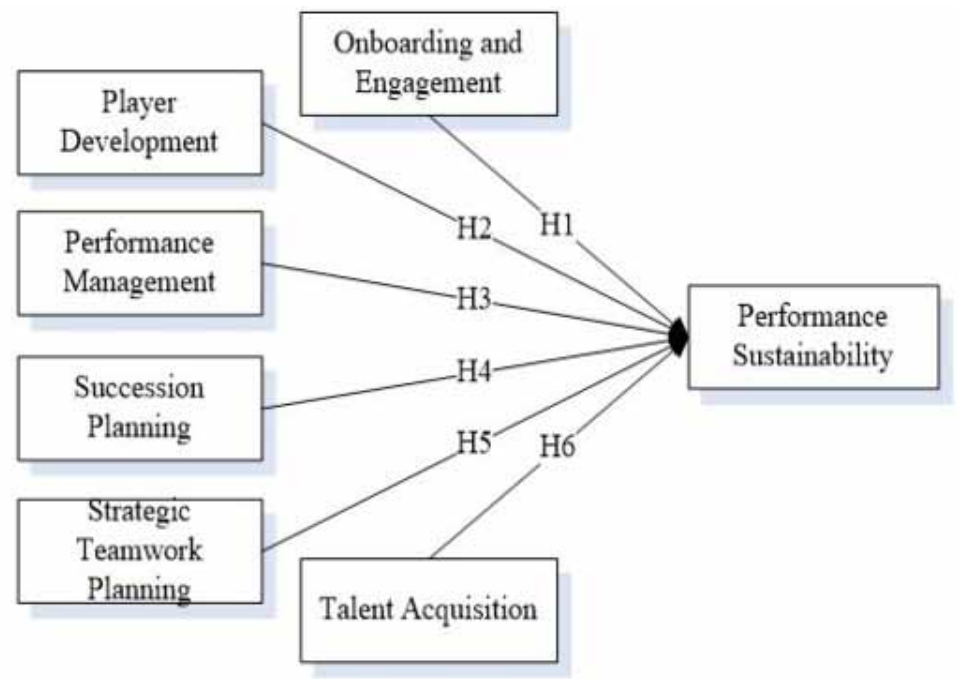

(BKSP) for domestic and international matches. Three hundred seventy questionnaires were delivered to the cricketers, and 300 questionnaires were filled and submitted. In fact, this study's useable data was collected 270 through a period of one month, which exceeded the minimum calculated sample size (i.e., 146) using G*Power (Faul et al., 2007). The response rate is $81.11 \%$ for this data.

\subsection{Instrument Development}

First, onboarding and engagement were adapted from Mensah (2015). Second, player development was adapted from Tepayakul, et al. (2016). Third, performance management and succession planning were adapted from Tepayakul et al. (2016). Fourth, talent acquisition was adapted from Tepayakul et al., (2016) and Mensah (2015). Fifth, the authors developed scales for strategic teamwork planning and performance sustainability. Due to the unavailability of the scale, we developed a scale following the method reported in Miah et al. (2017). We adopted the mixed method-quantitative approach by conducting pilot study and -qualitative method through online focus group study among a group of potential respondents comprising teachers with diverse backgrounds, such as gender, education, age, income, geographical location, etc. Moreover, we made few changes to the structured items through focus group study and pre-testing among academicians, coach, manager and researcher Finally, all scale items except the demographic variable were rated using a 5-point Likert scale ranging from strongly disagree (1) to strongly agree (5).

\section{RESULTS}

\subsection{Method Bias}

Firstly, data were screened to find missing values and outliers for further analysis that reports no defective case. Harman's single-factor assessment is $35.43 \%$ less than the threshold value of $50 \%$ (Fuller et al., 2016; Podsakoff et al., 2003). So, there is no problem in the data set using common method bias (CMB). The collinearity test is shown for testing CMB under PLS-SEM. If the VIF value is greater than 3.30 for reflective indicators, it shows CMB (Hair et al., 2017; Kock, 2015). Hence, all VIF values are less than the threshold value, ranging from 1.480 to 3.145 ; thus, the data has not suffered by CMB problem. 


\subsection{Demographic Information of Respondents}

The respondents' profile is presented in Table $1.67 .8 \%$ of data were collected from BCB and the remaining from BKSP, and the percentage between males and females is $72.6 \%$ and $27.4 \%$, respectively. The majority of respondents was 14-24 years old (53.7\%), and the greater part of educational qualification was higher secondary (31.5\%). Furthermore, the prime level of engagement for playing was a trainee (30.4\%), junior cricketer (30.7\%), and senior cricketer (31.1\%). On the other hand, most of the participants' income levels were less than 10,000 , covered by $33.3 \%$.

\subsection{Measurement Model}

Next, the current study was performed following the two-stage SEM approach (Jilani, Fan, Islam, \& Uddin, 2020; Uddin, Akter, Al-Amin, Rahman, \& Ferdausy, 2020; Uddin, Priyankara, \& Mahmood, 2020). These two stages are the measurement model and structural model (Azim, Fan, Uddin, Jilani, \& Begum, 2019; Das, Biswas, Jilani, \& Uddin, 2019; Fan, Mahmood, \& Uddin, 2019; Mahmood, Uddin, \& Luo, 2019). We selected PLS-SEM over because this research's primary purpose was prediction (Hair et al., 2017; Shih \& Putri, 2016). The measurement model was examined by using internal reliability, convergent validity, and discriminant validity (Hair et al., 2017). Indeed, all the computed values of Cronbach's Alpha as well as composite reliability are above threshold values, such as 0.70 (Hair et al., 2017). Convergent validity is also satisfied where all the values of AVE exceed the threshold value of 0.50 (Hyun, Weisheng, \& Jung-sup, 2018).

\section{Table 1. Profile of Respondents}

\begin{tabular}{|c|c|c|c|}
\hline Variables & Category & Frequency & $\%$ \\
\hline \multirow{2}{*}{ Area } & BCB, Dhaka & 183 & 67.8 \\
\hline & BKSP, Savar & 87 & 32.2 \\
\hline \multirow{2}{*}{ Gender } & Male & 196 & 72.6 \\
\hline & Female & 74 & 27.4 \\
\hline \multirow{4}{*}{ Age } & Less than 24 & 160 & 59.2 \\
\hline & $25-35$ & 92 & 34.1 \\
\hline & $36-46$ & 11 & 4.1 \\
\hline & 47 through Highest & 7 & 2.6 \\
\hline \multirow{4}{*}{ Educational qualification } & Graduate & 42 & 15.6 \\
\hline & Higher secondary & 85 & 31.5 \\
\hline & Secondary & 54 & 20.0 \\
\hline & Others & 89 & 32.9 \\
\hline \multirow{5}{*}{ Level of engagement for playing } & Trainee & 82 & 30.4 \\
\hline & Junior Cricketer & 83 & 30.7 \\
\hline & Senior Cricketer & 84 & 31.1 \\
\hline & Retired Cricketer & 19 & 7.0 \\
\hline & Others & 2 & 0.7 \\
\hline \multirow{4}{*}{ Income levels } & Less than 20,000 & 154 & 57.0 \\
\hline & $20,000-30,000$ & 54 & 20.0 \\
\hline & $30,000-40,000$ & 27 & 10.0 \\
\hline & 40,000 above & 35 & 13.0 \\
\hline
\end{tabular}


The discriminant validity (Fornell \& Larcker, 1981) was examined using the correlation matrix and the AVE's square root, which shows the bold diagonal value in Table 2. To test discriminant validity, the AVE of a construct's square root should be greater than its associated correlation with other constructs of the corresponding row and column values (Hair et al., 2017). As shown in Table 3 , the square root of AVE was higher than the corresponding correlation values that confirm data's discriminant validity. Therefore, validity issue has been satisfied and achieved (Das, Abdul Kader Jilani, Uddin, Uddin, \& Ghosh, In Press; Mahmood, Uddin, Ostrovskiy, \& Orazalin, 2020; Yi, Uddin, Das, Mahmood, \& Sohel, 2019).

\subsection{Structural Model}

Firstly, collinearity issues were examined for testing the structural model. The values of the Variance Inflation Factor (VIF) were ranging from 1.480 to 3.145, which were less than the threshold value of 3.33 (Mahmood et al., 2019). Hence, this study argues that there is no collinearity problem. Next, Figure 2 shows the validate proposed research model of this study, and also Table 3 presents the outcomes direct effects that were analyzed using the bootstrap 5000 re-sampling technique. The coefficient of determination ( $\mathrm{R}^{2}$ value) is generally used to assess the structural model. The $\mathrm{R}^{2}$ value was utilized to assess the difference clarified by the independent variables in the structural model (Klarner et al., 2013). As shown in Figure 2, the values of $\mathrm{R}^{2}$ of performance sustainability with .705, which is a substantial effect, and player development with .489 moderate influence to yield dependent variables (Hair, Ringle, \& Sarstedt, 2011).

As per the results in Table 3, two hypotheses of direct path relationships were not supported. Results also pointed out that onboarding and engagement, performance management, player development, and strategic teamwork planning were positive influences on performance sustainability, with $(\beta=0.108$, $\mathrm{t}=2.347, \mathrm{p}<0.019),(\beta=0.208, \mathrm{t}=4.068, \mathrm{p}<0.000),(\beta=0.297, \mathrm{t}=4.613, \mathrm{p}<0.000),(\beta=0.291, \mathrm{t}=5.073$, $\mathrm{p}<0.000)$ respectively. Consequently, the association between performance management and player development $(\beta=0.699, t=15.608, p>0.000)$ were a significant positive impact. In short, among seven hypotheses of direct associations, $\mathrm{H} 4$ and $\mathrm{H} 7$ were not accepted.

\section{DISCUSSION}

In this study, the structural modeling approach was applied to understand the connection between talent management practices and professional cricketers' sustainability. In a way, the empirical finding

Table 2. Estimates on Reliabilities and Validities

\begin{tabular}{|l|l|l|l|l|l|l|l|}
\hline \multicolumn{1}{|c|}{ Constructs } & \multicolumn{1}{|c|}{$\mathbf{1}$} & $\mathbf{2}$ & $\mathbf{3}$ & $\mathbf{4}$ & $\mathbf{5}$ & $\mathbf{6}$ & $\mathbf{7}$ \\
\hline Onboarding and Engagement (1) & $\mathbf{0 . 7 5 3}$ & & & & & & \\
\hline Performance Management (2) & 0.497 & $\mathbf{0 . 8 3 2}$ & & & & & \\
\hline Performance Sustainability (3) & 0.604 & 0.718 & $\mathbf{0 . 7 7 2}$ & & & & \\
\hline Player Development (4) & 0.580 & 0.699 & 0.758 & $\mathbf{0 . 7 5 9}$ & & & \\
\hline Strategic Teamwork Planning (5) & 0.602 & 0.720 & 0.763 & 0.719 & $\mathbf{0 . 7 6 3}$ & & \\
\hline Succession Planning (6) & 0.546 & 0.377 & 0.428 & 0.373 & 0.412 & $\mathbf{0 . 7 5 5}$ & \\
\hline Talent Acquisition (7) & 0.589 & 0.620 & 0.673 & 0.753 & 0.692 & 0.431 & $\mathbf{0 . 7 4 2}$ \\
\hline Cronbach's Alpha & 0.813 & 0.776 & 0.885 & 0.815 & 0.820 & 0.812 & 0.859 \\
\hline Composite Reliability & 0.867 & 0.870 & 0.911 & 0.871 & 0.874 & 0.869 & 0.859 \\
\hline Average Variance Extracted & 0.568 & 0.692 & 0.596 & 0.575 & 0.582 & 0.570 & 0.551 \\
\hline
\end{tabular}


Table 3. Outcomes of Direct effects

\begin{tabular}{|l|l|l|l|l|l|}
\hline \multicolumn{1}{|c|}{ Hypotheses } & \multicolumn{1}{|c|}{ Path Relationship } & \multicolumn{1}{|c|}{ Beta $(\boldsymbol{\beta})$} & \multicolumn{1}{|c|}{ T Statistics } & \multicolumn{1}{|c|}{ P Values } & \multicolumn{1}{|c|}{ Decisions } \\
\hline$H 1$ & OE-> PS & 0.108 & 2.347 & 0.019 & Supported \\
\hline$H 2$ & PD-> PS & 0.297 & 4.613 & 0.000 & Supported \\
\hline$H 3$ & PM-> PS & 0.208 & 4.068 & 0.000 & Supported \\
\hline$H 4$ & SP-> PS & 0.044 & 1.031 & 0.303 & Not Supported \\
\hline$H 5$ & STP-> PS & 0.291 & 5.073 & 0.000 & Supported \\
\hline$H 6$ & TA-> PS & 0.035 & 0.683 & 0.495 & Not Supported \\
\hline
\end{tabular}

Note: OE. Onboarding and engagement, PS. Performance sustainability, PD. Player development, PM. Performance management, SP. Succession planning, STP. Strategic teamwork planning, TA. Talent acquisition

Figure 2. Results Wise Validate Structural Model

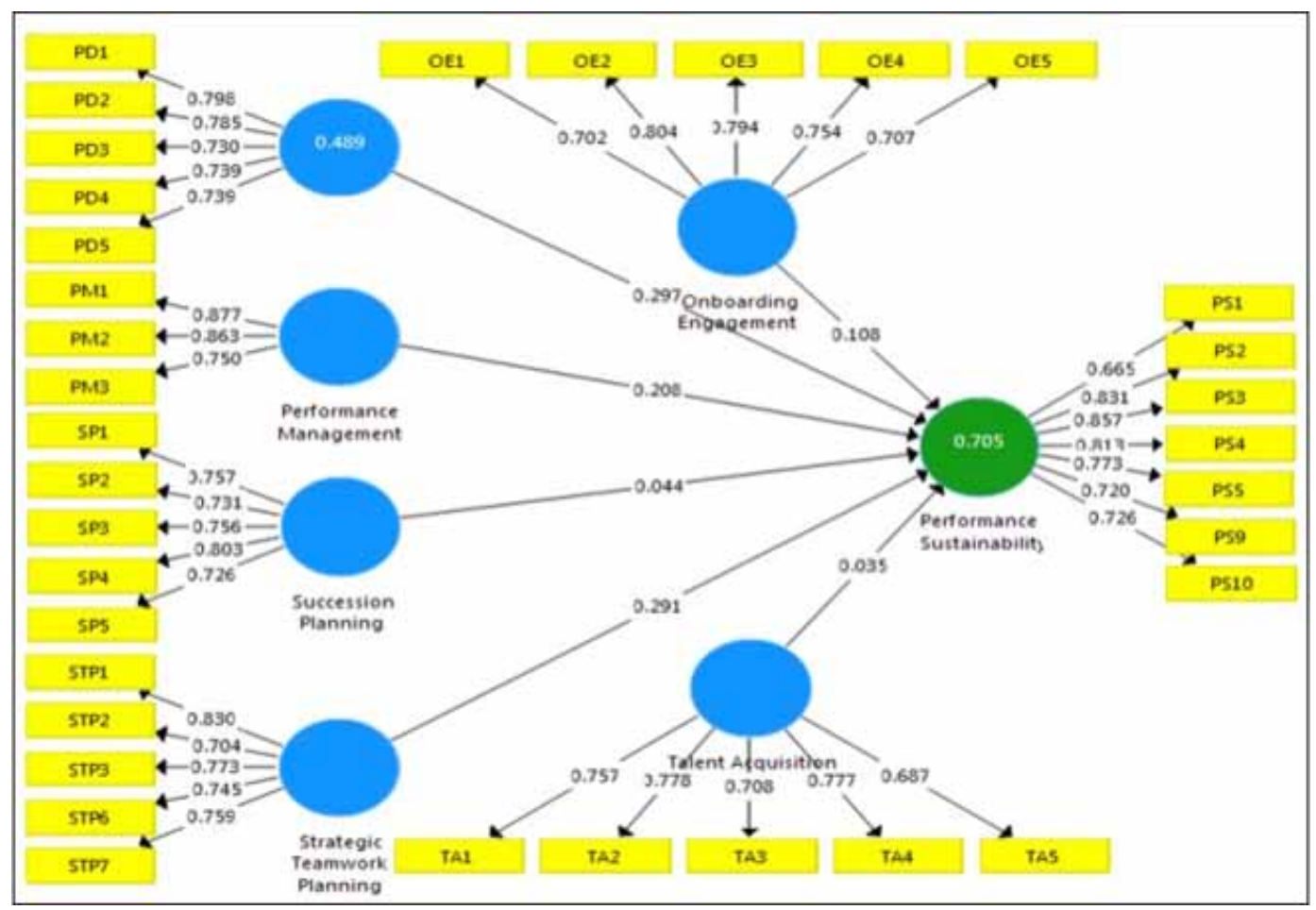

can provide much information regarding talent management practices and the cricketers' performance sustainability in Bangladesh Cricket Broad. The result is remarkable through the structural equation model because it introduces and validates the measurement and structural model in an integrated manner (Hair et al., 2017). Furthermore, among the seven hypotheses, five were supported, while two were rejected.

Concerning the factors that significantly predict the sustainable performances, it was observed that onboarding \& engagement $(\beta=0.108 ; p=0.019)$, player development $(\beta=0.297 ; p=0.000)$, performance management $(\beta=0.208 ; p=0.000)$, and strategic teamwork planning $(\beta=0.291 ; p=0.000)$ all had a positive and significant impact on performance sustainability. In addition, it was also observed that performance management $(\beta=0.699 ; p=0.000)$ had a positive significant effect on player development. 
These findings only supported player development's performance management factor (De Knop, Van Hoecke, \& De Bosscher, 2004). Lastly, it was observed that succession planning ( $\beta=0.044 ; p=0.303)$, talent acquisition $(\beta=0.035 ; \mathrm{p}=0.495$ ) all had no significant impact on performance sustainability. These findings did not support the succession-planning factor affecting performance sustainability and the talent acquisition factor affecting performance sustainability in respectively (Shibli, 1999).

\subsection{Theoretical Contributions}

This study theoretically extends the literatures on performance sustainability and its antecedents to trigger continuity of performance. Prior studies showed that the effect of talent management on employee (Mensah, 2019) and organization performance (Al Aina \& Atan, 2020; Collings et al., 2019; Son et al., 2020; Latukha \& Veselova, 2019; Almaaitah et al., 2020). Furthermore, our study also theoretically contributes to talent management literature and how the different dimensions of talent management influence performance sustainability. To best our knowledge, this study is going to be the first research on sports industry, especially in Bangladesh contexts. This study confirmed that all dimensions of talent management practices significantly affect the cricketers' performance sustainability. Precisely, performance management $(\beta=0.699)$ has the most substantial impact on the cricketers' performance sustainability. In contrast, the succession planning $(\beta=0.044)$ and talent acquisition ( $\beta=0.035$ ) have the lowest insignificant effect on the cricketers' performance sustainability in Bangladesh Cricket Broad. In addition to onboarding and engagement, player development and strategic teamwork planning have a significant positive effect on performance sustainability regarding the cricketers in Bangladesh Cricket Broad.

\subsection{Practical Implications}

In addition to the above discussed several theoretical contributions, our study also implies some practical contributions for applying talent management for performance sustainability. First, our results show that players' onboarding and engagement can enhance performance regularly. Thus, team coordinators, managers and human resources manager would attract players through providing rewards and recognitions extrinsically and intrinsically. As a result, performer will more likely to engage in better performance. Second, our results also showed that sustainable performance could be achieved through ensuring player development. Team coaches and human resource managers might arrange training and workshops that would elicit the skill of talent. Third, the next results of our study prove that effective performance management promotes continuity of performance. Thus, human resource manager should ensure performance appraisal and provide different facilities for magnifying performance. Fourth, this study demonstrate that strategic teamwork raises sustainable performance. Thus, management of organization should initiate strategic planning depending on expertise, time, internal capacities, environment and competitors' assessment.

Finally, we observed that the performance sustainability will be obtained through accurate talents' selection. Hence, human resource managers must demonstrate their dexterity while hunting the right talents. These results will be worthwhile for the cricket broads, especially management departments, including batting, blowing, fielding. Moreover, this study will significantly help both sports coordinators and team managers know more and improve their core understanding. This study will also help guide the Bangladesh cricket policymakers in managing talent regarding performance in the sports organization. Also, the sports researchers will be able to pay adequate attention to talent management practices and performance sustainability-related activities to help enhance the professional cricketers' sustainable performance and goodwill.

\subsection{Limitations and Future Research Directions}

This study is not without some potential limitations. Firstly, this study was conducted with small samples from BCB, Dhaka, and BKSP, Savar in Bangladesh. So, the findings may not be able to represent in favor of the entire professional cricketers. Future research should give special importance 
to conducting in this area by taking more cricketers that are professional. Secondly, this study was only conducted among cricketers. Therefore, future researchers should pay more attention to other sports sectors. Thirdly, this study was only done on the Bangladeshi cricketers. Therefore, future research should emphasize the foreign cricketers through conducting cross-cultural research more effectively. Lastly, the various demographic conditions and independent variables can strengthen talent management practices on performance sustainability. So, potential future research can be done by mediating and moderating impacts of demographic or independent variables (i.e., national culture, creative skills, organizational support, learning climate) between talent management practices and performance sustainability.

\section{CONCLUSION}

This study examines the relationship between talent management practices and performance sustainability in sports organizations. The authors use talent management factors and consider other crucial factors that significantly influence on continuity of performance in a developing country's context. Different statistical analyses have been used in this study. The respondents of this study have identified some problems and given some suggestions related to the talent management practices and performance sustainability in BCB. 


\section{REFERENCES}

Al Aina, R., \& Atan, T. (2020). The Impact of Implementing Talent Management Practices on Sustainable Organizational Performance. Sustainability, 12(20), 8372. doi:10.3390/su12208372

Ali, Z., Mahmood, B., \& Mehreen, A. (2019). Linking succession planning to employee performance: The mediating roles of career development and performance appraisal. Australian Journal of Career Development, 28(2), 112-121. doi:10.1177/1038416219830419

Ali, Z., \& Mehreen, A. (2019). An empirical investigation of predicting employee performance through succession planning. Evidence-based HRM, 8(1), 79-91. doi:10.1108/EBHRM-11-2018-0069

Almaaitah, M., Alsafadi, Y., Altahat, S., \& Yousfi, A. (2020). The effect of talent management on organizational performance improvement: The mediating role of organizational commitment. Management Science Letters, 10(12), 2937-2944. doi:10.5267/j.msl.2020.4.012

Ashton, C., \& Morton, L. (2005). Managing talent for competitive advantage: Taking a systemic approach to talent management. Strategic HR Review, 4(5), 28-31. doi:10.1108/14754390580000819

Azim, M. T., Fan, L., Uddin, M. A., Jilani, M. M. A. K., \& Begum, S. (2019). Linking transformational leadership with employees' engagement in the creative process. Management Research Review, 42(7), 837-858. doi:10.1108/MRR-08-2018-0286

Bartlett, R., \& Hughes, M. (2015). The use of performance indicators in performance analysis. In Essentials of performance analysis in sport (pp. 117-140). Routledge. doi:10.4324/9781315776743

Bizen, Y., Kishida, K., Nogi, S., Kawakami, K., \& Yoshida, H. (2018). Consciousness of Spending on Children's Sports Activities in a Community Sports Club in Japan: Clarifying Parents' Internal Reference Price. International Journal of Asian Business and Information Management, 9(1), 13-22. doi:10.4018/IJABIM.2018010102

Burnes, B., \& O'Donnell, H. (2011). What can business leaders learn from sport? Sport, Business and Management, 1(1), 12-27. doi:10.1108/20426781111107144

Chakraborty, D., \& Biswas, W. (2020). Articulating the value of human resource planning (HRP) activities in augmenting organizational performance toward a sustained competitive firm. Journal of Asia Business Studies, 14(1), 62-90. doi:10.1108/JABS-01-2019-0025

Chillakuri, B. (2020). Understanding Generation Z expectations for effective onboarding, Journal of Organizational Change Management. 10.1108/JOCM-02-2020-0058

Collings, D. G., Mellahi, K., \& Cascio, W. F. (2019). Global talent management and performance in multinational enterprises: A multilevel perspective. Journal of Management, 45(2), 540-566. doi:10.1177/0149206318757018

Collings, D. G., Scullion, H., \& Dowling, P. J. (2009). Global staffing: A review and thematic research agenda. International Journal of Human Resource Management, 20(6), 1253-1272. doi:10.1080/09585190902909806

Da Silva, E. C., \& Las Casas, A. L. (2017). Sport fans as consumers: An approach to sport marketing. British Journal of Marketing Studies, 5(4), 36-48.

Das, A. K., Abdul Kader Jilani, M. M., Uddin, M. S., Uddin, M. A., \& Ghosh, A. K. (2021, May 19). Fighting ahead: Adoption of social distancing in COVID-19 outbreak through the lens of theory of planned behavior. Journal of Human Behavior in the Social Environment, 31(1-4), 373-393. Advance online publication. doi:10 $.1080 / 10911359.2020 .1833804$

Das, A. K., Biswas, S. R., Jilani, M. M. A. K., \& Uddin, M. A. (2019). Corporate Environmental Strategy and Voluntary Environmental Behavior-Mediating Effect of Psychological Green Climate. Sustainability, 11(11), 3123-3139. doi:10.3390/su11113123

De Knop, P., Van Hoecke, J., \& De Bosscher, V. (2004). Quality management in sports clubs. Sport Management Review, 7(1), 57-77. doi:10.1016/S1441-3523(04)70045-5

DeNisi, A. S., \& Murphy, K. R. (2017). Performance appraisal and performance management: 100 years of progress? The Journal of Applied Psychology, 102(3), 421-433. doi:10.1037/ap10000085 PMID:28125265 
Esfahani, P., Mosadeghrad, A. M., \& Akbarisari, A. (2018). The success of strategic planning in health care organizations of Iran. International Journal of Health Care Quality Assurance, 31(6), 563-574. doi:10.1108/ IJHCQA-08-2017-0145 PMID:29954262

Fan, L., Mahmood, M., \& Uddin, M. A. (2019). Supportive Chinese supervisor, innovative international students: A social exchange theory perspective. Asia Pacific Education Review, 20(1), 101-115. doi:10.1007/ s12564-018-9572-3

Faul, F., Erdfelder, E., Lang, A. G., \& Buchner, A. (2007). G* Power 3: A flexible statistical power analysis program for the social, behavioral, and biomedical sciences. Behavior Research Methods, 39(2), 175-191. doi:10.3758/BF03193146 PMID:17695343

Fornell, C., \& Larcker, D. F. (1981). Evaluating structural equation models with unobservable variables and measurement error. JMR, Journal of Marketing Research, 18(1), 39-50. doi:10.1177/002224378101800104

Fuller, C. M., Simmering, M. J., Atinc, G., Atinc, Y., \& Babin, B. J. (2016). Common methods variance detection in business research. Journal of Business Research, 69(8), 3192-3198. doi:10.1016/j.jbusres.2015.12.008

Gelens, J., Hofmans, J., Dries, N., \& Pepermans, R. (2014). Talent management and organisational justice: Employee reactions to high potential identification. Human Resource Management Journal, 24(2), 159-175. doi:10.1111/1748-8583.12029

Gerrish, E. (2016). The impact of performance management on performance in public organizations: A metaanalysis. Public Administration Review, 76(1), 48-66. doi:10.1111/puar.12433

Ghai, K., \& Zipp, S. (2020). Governance in Indian cricket: Examining the Board of Control for Cricket in India through the good governance framework. Sport in Society, •••, 1-16. doi:10.1080/17430437.2020.1819598

Hair, J. F., Hult, G. T. M., Ringle, C. M., \& Sarstedt, M. (2017). A Primer on Partial Least Squares Structural Equation Modeling (PLS-SEM) (2nd ed.). Sage.

Hair, J. F., Ringle, C. M., \& Sarstedt, M. (2011). PLS-SEM: Indeed a silver bullet. Journal of Marketing Theory and Practice, 19(2), 139-152. doi:10.2753/MTP1069-6679190202

Henseler, J., Ringle, C. M., \& Sarstedt, M. (2015). A new criterion for assessing discriminant validity in variance-based structural equation modeling. Journal of the Academy of Marketing Science, 43(1), 115-135. doi:10.1007/s11747-014-0403-8

Hyun, B., Weisheng, C., \& Jung-sup, B. (2018). Exploring the Adoption of Sports Brand Apps: An Application of the Modified Technology Acceptance Model. International Journal of Asian Business and Information Management, 9(1), 52-65. doi:10.4018/IJABIM.2018010105

Jehanzeb, K. (2020). Does perceived organizational support and employee development influence organizational citizenship behavior? European Journal of Training and Development, 44(7), 637-667. doi:10.1108/EJTD-022020-0032

Jilani, M. M. A. K., Fan, L., Islam, M. T., \& Uddin, M. A. (2020). The Influence of Knowledge Sharing on Sustainable Performance: A Moderated Mediation Study. Sustainability, 12(3), 908. doi:10.3390/ su12030908

Kantor, B. S., Holdsworth, C. G., \& Barr, G. D. I. (2008). Evaluating performances at the 2007 cricket world cup. South African Statistical Journal, 42(2), 125-142.

Kerr, A. K., \& Gladden, J. M. (2008). Extending the understanding of professional team brand equity to the global marketplace. International Journal of Sport Management and Marketing, 3(1-2), 58-77. doi:10.1504/ IJSMM.2008.015961

Khurshid, R., \& Darzi, M. A. (2016). Managing talent for competitive advantage. International Journal of Applied Research, 2(2), 569-571.

Klarner, P., Sarstedt, M., Hoeck, M., \& Ringle, C. M. (2013). Disentangling the effects of team competences, team adaptability, and client communication on the performance of management consulting teams. Long Range Planning, 46(3), 258-286. doi:10.1016/j.lrp.2013.03.001 
Kock, N. (2015). Common method bias in PLS-SEM: A full collinearity assessment approach. International Journal of e-Collaboration, 11(4), 1-10. doi:10.4018/ijec.2015100101

Kwak, D. H., \& Pradhan, S. (2020). “If You Ain’t First, You're Last!” Understanding Identity Threat, Team Identification, and Advertisement Messages When Your Favorite Team Loses. Journal of Sport Management. Advance online publication. doi:10.1123/jsm.2019-0445

Latukha, M., \& Veselova, A. (2019). Talent management, absorptive capacity, and firm performance: Does it work in China and Russia? Human Resource Management, 58(5), 503-519. doi:10.1002/hrm.21930

Leng, H. K., \& Lin, Y.-C. (2018). Special Issue on Sports and Leisure Marketing in Asia Preface. International Journal of Asian Business and Information Management, 9(1), iv-vi.

Mahmood, M., Uddin, M. A., \& Luo, F. (2019). Influence of Transformational Leadership on Employees' Creative Process Engagement: A Multi-Level Analysis. Management Decision, 57(3), 741-764. doi:10.1108/ MD-07-2017-0707

Mahmood, M., Uddin Md, A., Ostrovskiy, A., \& Orazalin, N. (2020). Effectiveness of business leadership in the Eurasian context: Empirical evidence from Kazakhstan. Journal of Management Development, 39(9), $793-809$. doi:10.1108/JMD-05-2019-0154

Maqueira, J. M., Bruque, S., \& Uhrin, Á. (2019). Talent management: Two pathways to glory? Lessons from the sports arena. Employee Relations, 41(1), 34-51. doi:10.1108/ER-11-2017-0271

Martindale, R. J., Collins, D., \& Abraham, A. (2007). Effective talent development: The elite coach perspective in UK sport. Journal of Applied Sport Psychology, 19(2), 187-206. doi:10.1080/10413200701188944

McDonnell, A. (2011). Still fighting the "war for talent”? Bridging the science versus practice gap. Journal of Business and Psychology, 26(2), 169-173. doi:10.1007/s10869-011-9220-y

Megheirkouni, M. (2017). Leadership styles and organizational learning in UK for-profit and non-profit sports organizations. The International Journal of Organizational Analysis, 25(4), 596-612. doi:10.1108/IJOA-072016-1042

Mensah, J. K. (2015). A “coalesced framework" of talent management and employee performance: For further research and practice. International Journal of Productivity and Performance Management, 64(4), 544-566. doi:10.1108/IJPPM-07-2014-0100

Mensah, J. K. (2019). Talent management and employee outcomes: A psychological contract fulfilment perspective. Public Organization Review, 19(3), 325-344. doi:10.1007/s11115-018-0407-9

Miah, S. J., Hasan, N., Hasan, R., \& Gammack, J. (2017). Healthcare support for underserved communities using a mobile social media platform. Information Systems, 66, 1-12. doi:10.1016/j.is.2017.01.001

Moghtadaie, L., \& Taji, M. (2016). Study of the performance of faculty members according to talent management approach in higher education. Educational Research Review, 11(8), 781-790.

Pandey, N. (2018). Predicting players' performance in the game of cricket using machine learning (Doctoral dissertation). Laurentian University of Sudbury.

Pennell, K. (2010). The role of flexible job descriptions in succession management. Library Management, 31(4/ 5), 279-290. doi:10.1108/01435121011046344

Podsakoff, P. M., MacKenzie, S. B., Lee, J. Y., \& Podsakoff, N. P. (2003). Common method biases in behavioral research: A critical review of the literature and recommended remedies. The Journal of Applied Psychology, 88(5), 879-903. doi:10.1037/0021-9010.88.5.879 PMID:14516251

Ramey, M. H., Jawad, M., Naz, M., Yılmaz, A. K., \& Yazgan, E. (2019). The Impact of Employee Engagement on Job Insecurity by Moderating Role of Psychological Empowerment to Enhance Corporate Performance. International Journal of Asian Business and Information Management, 10(4), 72-88. doi:10.4018/ IJABIM.2019100106

Ronn, K. (2007). Rethinking talent acquisition. Business Week Online, 3(6). https://www.bloomberg.com/news/ articles/2020-10-07/pelosi-mnuchin-talk-airline-aid-after-trump-nixes-big-stimulus 
Shibli, S. (1999). The characteristics of volunteers in UK sports clubs. European Journal for Sport Management, $6,10-27$.

Shih, C. P., \& Putri, D. U. (2016). Measuring the Effect of Team Characteristics, Team Effectiveness on Organizational Performance, Organizational Survival and Competitiveness: A Case Study of an Indonesian NGO, Yayasan Cinta Anak Bangsa by using PLS Method. International Journal of Asian Business and Information Management, 7(2), 1-14. doi:10.4018/IJABIM.2016040101

Son, J., Park, O., Bae, J., \& Ok, C. (2020). Double-edged effect of talent management on organizational performance: The moderating role of HRM investments. International Journal of Human Resource Management, 31(17), 2188-2216. doi:10.1080/09585192.2018.1443955

Tan, S. Y., \& Pyun, D. Y. (2018). The Effectiveness of Sponsorship of the F1 Singapore Grand Prix: Recall and Recognition. International Journal of Asian Business and Information Management, 9(1), 1-12. doi:10.4018/ IJABIM.2018010101

Teo, D. (2018). Differences in Perceptions and Attitudes of Singaporean Female Football Fans Towards Football Marketing. International Journal of Asian Business and Information Management, 9(1), 23-38. doi:10.4018/ IJABIM.2018010103

Tepayakul, R., \& Rinthaisong, I. (2016). Finding Components of Talent Management System. Humanities, Arts and Social Sciences Studies, 16(3), 77-90.

Uddin, M. A., Akter, R., Al-Amin, M., Rahman, M. S., \& Ferdausy, S. (2020). How Do Socially Responsible Human Resource Management and Voluntary Green Behavior Influence Organizational Competitiveness? Studies in Business and Economics, 15(2), 243-255. doi:10.2478/sbe-2020-0038

Uddin, M. A., Priyankara, H. P. R., \& Mahmood, M. (2020). Does a creative identity encourage innovative behaviour? Evidence from knowledge-intensive IT service firms. European Journal of Innovation Management, 23(5), 877-894. doi:10.1108/EJIM-06-2019-0168

Wuen, C. H., Ibrahim, F., \& Ringim, K. J. (2020). The Impact of Human Resource Management Practices on SMEs Performance: An Exploratory Study in Brunei Darussalam. International Journal of Asian Business and Information Management, 11(2), 68-87. doi:10.4018/IJABIM.2020040105

Yeh, S.-W., Chen, M.-J., Chuang, C.-T., \& Lin, W.-B. (2018). Performance Evaluation of Teams in Chinese Professional Baseball League. International Journal of Asian Business and Information Management, 9(1), 39-51. doi:10.4018/IJABIM.2018010104

Yi, L., Uddin, M. A., Das, A. K., Mahmood, M., \& Sohel, S. M. (2019). Do Transformational Leaders Engage Employees in Sustainable Innovative Work Behaviour? Perspective from a Developing Country. Sustainability, 11(9), 2485-2502. doi:10.3390/su11092485 
Abdul Gaffar Khan is an Associate Professor in the Department of Management, Faculty of Business Studies, Mawlana Bhashani Science and Technology University, Bangladesh. He obtained BBA and MBA degree in Management from Islamic University, Bangladesh. He has been working as faculty member from 2012. His research interests focus on the areas of Human Resource Management, Innovation, Technology Adoption in Business and Health care sectors, Emotional Intelligence, HR Analytics, Digital HR and Knowledge Management etc. He has published several research papers in renowned national and international journals. One of them are published in ESCl and Scopus indexing journals.

Somiron Banik is a graduate student at the Faculty of Business Studies and Department of Business Administration, Mawlana Bhashani Science and Technology University, Bangladesh. He obtained his BBA degree from the same department. Meanwhile, his research interests focus on Human Resource Management areas such as Talent Management, Performance Management, and Compensation Management.

Md. Aftab Uddin is an Associate Professor in the Department of Human Resource Management, University of Chittagong, Bangladesh 4331. He does research on corporate greenization, creative engagement, innovative behavior, intelligence, leadership, proactive behavior, ICT in Business, and positive psychology which were published in Bangladesh, Brazil, Canada, China, India, Iran, Japan, Malaysia, Pakistan, Thailand, South Korea, Switzerland, United Arab Emirates, and United Kingdom. He published more than 60 research papers with numerous indexations, such as ABS, ABDC, SSCI, SCIE, Scopus, Scimago, etc. He is a regular reviewer of Journal of Business Research, Sage Open, IEEE Access, Asia Pacific Management Review, South Asian Journal of Human Resource Management, Management Research Review, International Journal of Innovation Management, Asia Pacific Journal of Management Research, and Team Performance Management: An International Journal, etc.

Syed Moudud-Ul-Huq (PhD.) is working as an Associate Professor of Accounting at Mawlana Bhashani Science and Technology University, Tangail-1902. He has more than thirty (30) published papers including two (02) SSCI, eight (08) Scopus, and eleven ESCI (web science indexed journals). His primary research interests are Financial Economics, Risk Management, Econometric Modeling, Corporate Governance, Financial Institutions etc. Besides of academic career, he is acting as an Editor of International Journal of Business Administration Research and reviewer of Bulletin of Economic Research, Financial Innovation, Economic Research, Cogent Economics and Finance, Cogent Business \& Management, etc. 